\title{
Reliability and validity of the Turkish version of the Lasa Physical Activity Questionnaire (LAPAQ)
}

\author{
Lasa Fiziksel Aktivite Anketinin (LAFAA) Türkçe Versiyonunun Güvenirliği ve Geçerliği
}

\section{${ }^{1}$ Saniye Aydoğan Arslan, ${ }^{1}$ Ayşe Abit Kocaman, ${ }^{1}$ Meral Sertel, ${ }^{2}$ Birol Onal, ${ }^{2}$ Tulin Duger, ${ }^{3}$ Arzu Demirguc,}

Kirrkkale University, Faculty of Health Sciences, Department of Physiotherapy and Rehabilitation, Kırıkkale, Turkey

${ }^{2}$ Hacettepe University, Faculty of of Physiotherapy and Rehabilitation, Ankara, Turkey

${ }^{3}$ Sanko University, Faculty of Health Sciences, Department of Physiotherapy and Rehabilitation University, Gaziantep, Turkey

\section{Correspondence:}

Saniye AYDOĞAN ARSLAN

Kırıkkale University, Faculty of Health Sciences, Department of Physiotherapy and Rehabilitation, Kırıkkale, Turkey

e-mail: fztsaniye1982@gmail.com

\section{Abstract}

LASA Physical Activity Questionnaire (LAPAQ) is frequently used for the elderly population in the literatüre, and its validity-reliability studies have been carried out. There are also comparative studies with other physical activity questionnaires. This study's aim is to investigate the reliability and validity of the Turkish version of the LAPAQ (LAPAQ-T) for elderly individuals. One hundred and seven elderly were included in the study. LAPAQ-T and Physical Activity Scale for the Elderly (PASE) were administered to the individuals participating in the study on the first day. LAPAQ-T was re-applied by the same physiotherapist 1 week after the first evaluation to measure test-retest reliability. The test-retest took place with the participation of 27 people. The intra-class correlation coefficient (ICC) was used to evaluate test-retest reliability. The ICC value for test-retest reliability was found to be 0.977 , which suggests excellent test-retest reliability. A high correlation was found between the LAPAQ-T total score and the PASE total score $(r=0.703, p<0.001)$. The results of our study show that the LAPAQ-T is a reproducible, reliable and valid questionnaire that evaluates the level of physical activity for elderly individuals. Therefore the questionnaire will be useful for clinicians in evaluating physical activity.

Keywords: Elderly, physical activity, reliability, validity

\section{Özet}

LASA Fiziksel Aktivite Anketi’ nin (LAFAA) literatürde yaşlı popülasyonda sıklıkla kullanılmakta ve geçerlik-güvenirlik çalışmaları yapılmış olup, diğer fiziksel aktivite anketleri ile karşılaştırmalı çalışmaları da bulunmaktadır. Bu çalışmanın amacı LAFAẢnın Türkçe Versiyonunun yaşlı yetişkinlerde güvenirliğini ve geçerliğini araştırmaktı. Çalışmaya yüz yedi yaşlı yetişkin dahil edildi. Çalışmaya katılan bireylere ilk gün LAFAA-T ve Yaşlılar için Fiziksel Aktivite Ölçeği (PASE) uygulandı. Test-tekrar test güvenilirliğini ölçmek için ilk değerlendirmeden 1 hafta sonra LAFAA-T aynı fizyoterapist tarafından tekrar uygulandı. Test-tekrar test 27 kişinin katılımı ile gerçekleşmiștir. Test-tekrar test güvenilirliğini değerlendirmek için sınıf içi korelasyon katsayısı (ICC) kullanıldı. Test-tekrar test güvenilirliği için ICC değeri 0,977 olarak bulundu, bu durum mükemmel test-tekrar test güvenilirliğini gösterdi. LAFAA-T toplam puanı ile PASE toplam puanı arasında yüksek ilişi bulundu $(\mathrm{r}=0.703, \mathrm{p}<0.001)$. Calışmamızın sonuçları, LAFAA-T’nin yaşlı yetişkinlerde fiziksel aktivite düzeyini değerlendiren tekrarlanabilir, güvenilir ve geçerli bir anket olduğunu göstermektedir. LAFAA-T’nin fiziksel aktiviteyi değerlendirmede klinisyenler için faydalı bir anket olacağını düșünüyoruz.

Anahtar Kelimeler: Yaşlı, fiziksel aktivite, güvenirlik, geçerlik 


\section{Introduction}

In recent years, the importance of physical activity has started to be further emphasized to remind that individuals are a productive part of society in old age, to eliminate the shortcomings, activity limitations and the limitations in social participation that occur with aging, and to ensure that they maintain their lives independently (1). Physical activity is considered as one of the most important components of physical and mental wellbeing in elderly individuals (2). Regular physical activity in the elderly is important to maintain health and functional ability. Furthermore, it has been shown in the studies that regular physical activity in elderly individuals has many beneficial effects on health and physical fitness. In addition to its effects on cardiovascular, neurophysiological, and musculoskeletal system health, it also has many proven benefits for body composition and metabolism (3). The complex structure of physical activity makes it difficult to evaluate it in all its aspects and investigate its effect on outcome parameters (e.g., energy expenditure). Due to this complex structure, there is no absolute gold standard in the evaluation of physical activity (4). Demographic features such as culture, sex and age, diseases, and motivation and cognitive functions are effective in determining physical activity. It is difficult and complex to determine the level of physical activity, especially in elderly individuals (5). Specific physical activity questionnaires have been developed for old individuals because they often have memory problems, faster fatigue response, and difficulty in following up their physical activity, and because they are less active than young people (6). These questionnaires are advantageous compared to other methods because they are cheap to use and provide ease of use in comprehensive studies. However, many of the questionnaires used to assess physical activity have been developed to assess young and middle-aged individuals (7-9). Physical activity questionnaires used in Turkey are limited. One of the questionnaires of which the Turkish version study has been carried out among physical activity questionnaires is the
International Physical Activity Questionnaire (IPAQ). Another one is the Physical Activity Assessment Questionnaire (PAAQ) developed and frequently used in our country. However, these questionnaires have been applied only to the young and middle-aged population and have not been applied to elderly individuals (10). The physical activity questionnaires frequently used in old individuals in the literature are the Community Health Activities Model Program for Seniors physical activity questionnaire (CHAMPS) (11), Yale Physical Activity Scale (YPAS) (6), and the Physical Activity Scale for the Elderly (PASE) (12). Among physical activity questionnaires for the elderly, PASE is the only questionnaire, the Turkish version study of which has been carried out (7). The LASA physical activity questionnaire (LAPAQ) for old individuals is one of these questionnaires. The LAPAQ for elderly individuals does not have a Turkish cultural adaptation and validity-reliability study, as other questionnaires frequently used in studies. The LAPAQ is frequently used for elderly population in the literature and its validity-reliability studies have been carried out, and there are also comparative studies with other physical activity questionnaires (9). Since its Turkish version and cultural adaptation studies have not been carried out, it cannot be used in studies conducted on elderly individuals in our country. The advantages of this questionnaire over others are its short application time, easy scoring, and applicability by letter or phone. Especially since there are not enough international questionnaires used in elderly population with proven validity and reliability, it is difficult to make an evaluation in elderly individuals due to the physical and mental problems in them. Therefore, an international questionnaire with the proven validity and reliability in our country has become an important deficiency and need in the evaluation of elderly individuals.

This study's aim is to investigate the reliability and validity of the Turkish Version of the LAPAQ (LAPAQ-T) in elderly individuals. 


\section{Materials and Methods}

\section{Patients and Setting}

Volunteers over 65 years of age who applied to the Physiotherapy and Rehabilitation Department were included in the study.

The individuals who volunteered to participate in the study were signed the informed consent form. This study was approved by the Non-Interventional Research Ethics Committee of Hacettepe University (Decision No: GO 18/261-37). The sociodemographic data (age, height, weight, educational level, marital status, etc.), background, family history, and history of fall of all the individuals who participated in the study were recorded. The Mini-Mental State Examination (MMSE) was used to determine the general cognitive status of elderly individuals. Volunteer individuals over 65 years of age, with a good cognitive level (13) (MMSE of 24 and above), who could be mobilized independently were included in the study. Elderly individuals who had severe chronic diseases (cardiovascular disease, chronic obstructive pulmonary disease, uncontrollable hypertension, diabetes, etc.) that might be contraindicated for moderate and intense physical activity, were diagnosed with cognitive disorder and had undergone surgery in the last six months were not included in the study.

LAPAQ-T and PASE were administered to the individuals participating in the study on the first day. LAPAQ-T was re-applied by the same physiotherapist 1 week after the first evaluation to measure the test-retest reliability.

\section{Instruments}

\section{LASA Physical Activity Questionnaire}

The LAPAQ is a face-to-face questionnaire that covers outdoor walking, cycling, gardening, light home activities, heavy household activities, sports and maximum living conditions. The activities carried out in the last two weeks are questioned. It includes a total of 31 questions. Scoring in the LAPAQ is performed according to the duration of activities: the activity durations are classified as $0,1-15,16-30,31-60$ and $61-120 \mathrm{~min}$ and $>$ $120 \mathrm{~min}$ per day and are scored as $0,1,2,3,4$, and 5, respectively. For each activity, the total score of the LAPAQ within two weeks is calculated by multiplying the frequency of the activity and the time score. For example, if an individual walked for 45 min 8 times in the last two weeks, the total score is $3 \times 8=24$. If he walked more than once in a day, the total time in two weeks is calculated, and the average time in one day is calculated by dividing it by 14. The point equivalent of this time is multiplied by 14 . For example, if an individual walked for $10 \min 45$ times in two weeks $(45 \times 10) / 14=32$ minutes $=3$ points, and the total score $=3 \times 14=42$. The total activity score is calculated by summing the scores of all activities over two weeks (9). High scores show better physical activity levels.

\section{Scoring of the Physical Activity Scale for the Elderly}

The validity of a measuring instrument can be determined by comparing that measuring instrument with other known and accepted measurements. To this end, PASE, of which validity and reliability studies in Turkish have been carried out, was used to test its validity in the study (7). PASE was developed in 1993 to evaluate the leisure, work, and household physical activity components. The PASE can be applied by personal interview, telephone, or post. The PASE questions participants' walking, mild, moderate and intense sports and recreation activities, muscle strength and endurance exercises, work-related activities including walking and standing, lawn and garden maintenance, care of another person, home repair, the intensity, frequency, and duration of heavy and light household activities within the last week. The PASE score is calculated based on the weight of a PASE assigned for each of the different activities that the participants took part in within the last week. Activity frequencies and activity weights are multiplied to obtain the PASE scores of activities. The PASE scoring 
is done without including the question of sitting activities, which is the first one of leisure time activity questions, in the evaluation (12).

\section{Translation and Cross-Cultural Adaptation}

First of all, to study the validity and reliability of the LAPAQ, permission was obtained from the owner of the scale, Vianda S Stel, and the guidelines of Beaton et al. were used for transcultural compatibility during the translation process (14). The original questionnaire was independently translated into Turkish. In the first stage, it was translated into Turkish by two independent experts who knew English at a good level. Two separate Turkish translations were compared by the researchers for inconsistencies. After comparison, a Turkish version was obtained. These text were again translated into English by two independent people, who were English native speakers and who knew Turkish at a good level and were far from medicine The Turkish version was compared with the original English version to detect possible interpretation errors and nuances that might have been overlooked. The Turkish version was then jointly evaluated by four translators, domain expert researchers to assess the need for cultural adaptation. After a pilot study was performed on 20 elderly individuals, the LAPAQ was finalized into Turkish without cultural adaptations.

\section{Statistical Analysis}

\section{Reliability}

Test-retest reliability is one of the most commonly used reliability analysis methods. Test-retest reliability is found by giving a measuring instrument to the same group, with two different applications under the same conditions and then by calculating the correlation of the scores obtained in these two applications. To determine the test-retest reliability in the study, the Turkish version of the LAPAQ was applied again after one week considering this parameter. The test-retest took place with the participation of 27 people. The intra-class correlation coefficient (ICC) was used to evaluate test-retest reliability. The ICC varies between 0.00 and 1.00. Values between 0.50 and 0.75 indicate modarete reliability, between 0.75 and 0.90 indicate good reliability and values above 0.90 indicate excellent reliability (15). Cronbach's alpha coefficient $(\alpha)$ was calculated for internal consistency. Cronbach's alpha value is $\geq 0.9$ excellent, $0.7 \leq \alpha<0.9$ good, $0.6 \leq \alpha<0.7$ acceptable, $\quad 0.5 \leq \alpha<0.6$ weak, $\alpha<0.5$ unacceptable (16).

\section{Validity}

In this study, construct validity was evaluated by comparing the results of the LAPAQ and PASE. The construct validity coefficients (r) were accepted as 0.81-1.0 excellent, 0.61-0.80 very good, 0.41-0.60 good, 0.21-0.40 moderate, and 0-0.20 weak. Construct validity was measured with the Spearman correlation coefficient (17).

\section{Results}

\section{Demographic Characteristics}

One hundred and seven elderly individuals (41 females and 66 males) were included in the study. The test-retest was completed with 27 people. The socio-demographic data of individuals are shown in Table 1.

Table 1. Socio-Demographic Characteristics and Clinic Data of the Elderly individuals (n: 107)

\begin{tabular}{lll}
\hline & & Min-Maks \\
\hline Age, years, mean \pm SD & $71.66 \pm 3.87$ & $66-79$ \\
Height, cm, mean \pm SD & $165.40 \pm 8.27$ & $145-183$ \\
Weight, kg, mean \pm SD & $75.75 \pm 12.03$ & $52-115$ \\
Body mass index, kg/m², mean \pm SD & $27.81 \pm 4.70$ & $18.52-42.22$ \\
\hline
\end{tabular}




\begin{tabular}{|c|c|c|}
\hline Gender & & \\
\hline Female, n (\%) & $41(38.3)$ & \\
\hline Male, n (\%) & $66(61.7)$ & \\
\hline LAPAQ, mean \pm SD $(n=107)$ & $45.62 \pm 36.67$ & $0-156$ \\
\hline PASE, mean \pm SD $(n=107)$ & $64.60 \pm 45.24$ & $0-183.50$ \\
\hline
\end{tabular}

\section{Test-Retest Reliability}

There was a very high correlation between the LAPAQ-T 1st and 2nd measurement values $(\mathrm{r}=0.940, \mathrm{p}<0.001)($ Table 2$)$. The ICC value for test-retest reliability was found to be 0.977 $(0.948-0.990)$ at the confidence interval of $95 \%$, which suggests excellent test-retest reliability. Cronbach's alpha coefficient was found to be 0.663 (acceptable).

Table 2. Test-retest reliability subheadings and the total score with respect to the Turkish version of the LAPAQ.

$\begin{array}{lcc}\mathrm{n}=\mathbf{2 7} & \mathrm{r} & \mathrm{p} \\ \text { walking } & 0.759 & \mathrm{p}<0.001 * \\ \text { gardening } & 0.805 & \mathrm{p}<0.001 * \\ \text { bicycling } & - & - \\ \text { Light household } & 0.912 & \mathrm{p}<0.001 * \\ \text { Heavy household } & 0.911 & \mathrm{p}<0.001 * \\ \text { Sports } & 0.789 & \mathrm{p}<0.001 * \\ \text { Total LASA PAQ } & 0.940 & \mathrm{p}<0.001 * \\ \text { *p } p \text { 0.001; Spearman's correlation analysis, } & \text { LAPAQ: LASA Physical Activity Questionnaire }\end{array}$

Construct Validity: A high correlation was found between the LAPAQ-T total score and the PASE total score $(\mathrm{r}=0.703, \mathrm{p}<0.001)$ (Table 3). A good correlation was found between the LAPAQ-T light household score and heavy household score and the PASE household activities score $(r=0.621, \mathrm{p}<0.001$ and $\mathrm{r}=0.445, \mathrm{p}<0.001$ respectively)

Table 3. Correlation Coefficients Between the subscale scores of LAPAQ-T and PASE

\begin{tabular}{|c|c|c|c|c|}
\hline LASA subheadings & $\begin{array}{l}\text { PASE } \\
\text { Leisure time activities }\end{array}$ & $\begin{array}{l}\text { PASE } \\
\text { Household activities }\end{array}$ & $\begin{array}{l}\text { PASE } \\
\text { Work-related activities }\end{array}$ & $\begin{array}{l}\text { PASE } \\
\text { Total }\end{array}$ \\
\hline walking & $\begin{array}{l}r=0.362 \\
p=0.001\end{array}$ & $\begin{array}{l}\mathrm{r}=0.121 \\
\mathrm{p}=0.218\end{array}$ & $\begin{array}{l}r=-0.129 \\
p=0.189\end{array}$ & $\begin{array}{l}r=0.302 \\
p=0.002 *\end{array}$ \\
\hline gardening & $\begin{array}{l}r=0.173 \\
p=0.078\end{array}$ & $\begin{array}{l}\mathrm{r}=0.182 \\
\mathrm{p}=0.063\end{array}$ & $\begin{array}{l}r=-0.043 \\
p=0.664\end{array}$ & $\begin{array}{l}\mathrm{r}=0.223 \\
\mathrm{p}=0.022 *\end{array}$ \\
\hline bicycling & $\begin{array}{l}r=0.058 \\
p=0.555\end{array}$ & $\begin{array}{l}r=-0.127 \\
p=0.197\end{array}$ & $\begin{array}{l}\mathrm{r}=-0.010 \\
\mathrm{p}=0.922\end{array}$ & $\begin{array}{l}r=-0.076 \\
p=0.441\end{array}$ \\
\hline Light household & $\begin{array}{l}r=0.122 \\
p=0.215\end{array}$ & $\begin{array}{l}\mathrm{r}=0.621 \\
\mathrm{p}=0.001 *\end{array}$ & $\begin{array}{l}\mathrm{r}=-0.105 \\
\mathrm{p}=0.284\end{array}$ & $\begin{array}{l}\mathrm{r}=0.532 \\
\mathrm{p}=0.001 *\end{array}$ \\
\hline Heavy household & $\begin{array}{l}\mathrm{r}=0.271 \\
\mathrm{p}=0.005^{*}\end{array}$ & $\begin{array}{l}\mathrm{r}=0.445 \\
\mathrm{p}=0.001^{*}\end{array}$ & $\begin{array}{l}\mathrm{r}=-0.058 \\
\mathrm{p}=0.555\end{array}$ & $\begin{array}{l}r=0.497 \\
p=0.001 *\end{array}$ \\
\hline Sports & $\begin{array}{l}\mathrm{r}=0.272 \\
\mathrm{p}=0.005^{*}\end{array}$ & $\begin{array}{l}\mathrm{r}=0.203 \\
\mathrm{p}=0.039 *\end{array}$ & $\begin{array}{l}\mathrm{r}=0.217 \\
\mathrm{p}=0.027\end{array}$ & $\begin{array}{l}r=0.309 \\
p=0.001\end{array}$ \\
\hline Total LAPAQ-T & $\begin{array}{l}\mathrm{r}=0.427 \\
\mathrm{p}=0.001 *\end{array}$ & $\begin{array}{l}\mathrm{r}=0.625 \\
\mathrm{p}=0.001 *\end{array}$ & $\begin{array}{l}\mathrm{r}=-0.084 \\
\mathrm{p}=0.398\end{array}$ & $\begin{array}{l}r=0.703 \\
p=0.001 *\end{array}$ \\
\hline
\end{tabular}

${ }^{*} p<0.05$; Spearman's correlation analysis, LAPAQ-T: LASA Physical Activity Questionnaire Turkish Version; PASE: Physical Activity Scale for the Elderly 


\section{Discussion}

In this study, the psychometric properties of the LAPAQ-T were compared with the PASE commonly used in the clinic. The results of our study show that the LAPAQ-T is a reproducible, reliable and valid questionnaire that evaluates the level of physical activity in elderly individuals.

Measurements that objectively evaluate the physical activity, such as accelerometer and pedometer, are widely used. It is stated that self-reported surveys play an essential role in determining the level of physical activity in terms of reaching larger samples. At the same time, in terms of cost, it is emphasized that self-reported surveys are more advantageous than objective measurements (6). Recently, there has been an increasing interest in the evaluation of physical activity in older individuals in the literature. However, the important thing is the selection of an appropriate physical activity questionnaire for society. As far as we know, physical activity questionnaires specific to elderly individuals are very limited in Turkish society.

The LAPAQ is a scale created to determine the level of physical activity in older individuals. The LAPAQ is also frequently used in the literature $(19,20)$. However, upon examining the LAPAQ version studies, the number of the studies conducted is observed to be limited $(21,22)$. It draws attention that the validity of the LAPAQ has been assessed with the accelerometer and pedometer in previous studies, and a low relationship was found between the accelerometer and LAPAQ. For this reason, unlike the studies in the literature, PASE, which is used frequently in the clinic and whose validity and reliability has been made in the elderly with different cultures, was preferred to test the Turkish validity of this questionnaire (12).

The answers to some subheadings of the LAPAQ-T version draw attention. The number of people who answered yes to the cycling subheading in the questionnaire is only one. Most of the elderly individuals in our country do not have a habit of cycling. Furthermore, riding a bicycle is generally not preferred as a form of transportation in our society. Only 19 people answered questions about gardening activities. Conducting the study with individuals living in apartment buildings in large cities has brought along this result. From among 107 people, only 29 people stated that they did heavy housework, and 16 people did sports. It is reported that educational level, sex, and environmental factors such as seasons and residential areas may affect the physical activity level of individuals (8). The last two weeks are taken into account when evaluating the physical activity level in the LAPAQ. Our study was conducted between January-December 2019, and it is thought that the low physical activity level of people may have been adversely affected by the winter season. These factors should be taken into account in future studies.

A high positive correlation was found between the LAPAQ-T and PASE total scores. When reviewed in general, the fact that the two questionnaires contain similar activities explains this result. It was observed that the relationship levels between the LAPAQ-T and PASE subgroups were low. However, when the activities in its subcategories are examined, it is seen that LAPAQ questions the physical activities in more detail. For this reason, it was thought that there might be a low relationship between the sub-categories. When we compare the questionnaire content, the LAPAQ consists of six subheadings, and the PASE consists of three subheadings. For example, while walking, gardening, cycling, and sports are evaluated separately in the LAPAQ, these are calculated in a single subgroup as leisure activities in the PASE. In the LAPAQ, housework is scored separately as light and 
heavy housework. In the PASE, the total score is given to housework. It was seen that the housework subtitles of both questionnaires, had moderate relations with each other.

In their study, Stel et al. (9) used the pedometer for the LAPAQ validity and the $\log$ of activities they did during the last seven days. The activity $\log$ contains activities similar to the LAPAQ. They found a high correlation $(\mathrm{r}=0.68)$ between the LAPAQ and the 7-day $\log$ and a moderate correlation $(\mathrm{r}=0.56)$ with the pedometer. The repeatability of the LAPAQ was reasonably good (weighted kappa: 0.65-0.75).

In another study, it was observed that there was a low relationship between the LAPAQ and accelerometer, and there were large differences in the duration of physical activity calculated between the LAPAQ and the wristmounted accelerometer. The researchers stated that the difference between the methods was related to body mass index, disability level, and the presence of depressive symptoms. They indicated to researchers that they should take into account these differences when using questionnaires and/or accelerometers in future studies (23).

In a study conducted on elderly individuals in the Netherlands, the researchers compared the LAPAQ with the accelerometers and reported that the reproducibility of the LAPAQ was moderate, but there was a low relationship when they compared it with the accelerometer. Although the authors did not consider the LAPAQ suitable for the precise measurement of physical activity levels in elderly individuals they stated that it was a quick and practical self-administered questionnaire that could be used in practice and studies to determine whether a person's activity level is above the time recommended by the American College of Sports Medicine
(ACSM) and the American Heart Association (AHA) (21).

As a result, although their methods are different, studies on the original LAPAQ support the results of our study (9). The LAPAQ appears to be a valid and reliable questionnaire that assesses the level of physical activity in elderly individuals. It is important because it evaluates all six components of physical activity separately. There was no question that the participants said they did not understand and that did not fit the lifestyle when they were responding to the LAPAQ questions. This situation makes us think that the questionnaire is suitable for the lifestyle of Turkish elderly individuals. At the same time, the questionnaire is easy to score and answered in a short time, and there is no need for special training for practitioners. It is a questionnaire that can also be applied by telephone call. When analyzing it from these aspects, we think that the LAPAQ Turkish version will be a useful questionnaire for clinicians in evaluating physical activity.

\section{Declaration of interest}

Disclosure statement: No potential conflict of interest was reported by the authors.

Funding: This research received no specific grant from any funding agency in the public, commercial, or not-for-profit sectors.

\section{Acknowledgments}

The authors would like to express their gratitude to all the participants of the study.

*This study was approved by the NonInterventional Research Ethics Committee of Hacettepe University (Decision No: GO 18/261-37). 


\section{REFERENCES}

1. Netz Y, Wu M-J, Becker BJ, et al. Physical activity and psychological well-being in

2. Penedo FJ, Dahn JR. Exercise and wellbeing: a review of mental and physical health benefits associated with physical activity. Curr Opin Psychiatry. 2005;18:189-93.

3. Reiner $M$, Niermann C, Jekauc D, et al. Long-term health benefits of physical activity-a systematic review of longitudinal studies. BMC public health. 2013;13:813.

4. Schutz Y, Weinsier RL, Hunter GR. Assessment of free-living physical activity in humans: an overview of currently available and proposed new measures. Obes Res. 2001;9:368-79.

5. Hamer M, Chida YJ. Physical activity and risk of neurodegenerative disease: a systematic review of prospective evidence. Psychol Med. 2009;39:3-11.

6. Dipietro L, Caspersen CJ, Ostfeld AM, et al. A survey for assessing physical activity among older adults. Med Sci Sports Exerc. 1993;25:628-42

7. Ayvat E, Kilinc M, Kirdi N. The Turkish version of the Physical Activity Scale for the Elderly (PASE): its cultural adaptation, validation, and reliability. Turk $J$ Med Sci. 2017;47:908-15.

8. Washburn RA. Assessment of physical activity in older adults. Res $Q$ Exercise Sport. 2000;71:79-87.

9. Stel VS, Smit JH, Pluijm SM, et al. Comparison of the LASA Physical Activity Questionnaire with a 7-day diary and pedometer. J Clin Epidemiol. 2004;57:25258.

10. Saglam M, Arikan H, Savci S, et al. International physical activity questionnaire: reliability and validity of the Turkish version. Percept Mot Skills. 2010;111:278-84.

11. Stewart AL, Mills KM, King AC, et al. CHAMPS physical activity questionnaire for older adults: outcomes for interventions. Med Sci Sports Exerc. 2001;33:1126-41.

12. Washburn RA, Smith KW, Jette AM, et al. The Physical Activity Scale for the Elderly (PASE): development and evaluation. $J$ Clin Epidemiol. 1993;46:153-62.

13. Güngen C, Ertan T, Eker E, et al. Reliability and validity of the standardized Mini Mental State Examination in the diagnosis of mild dementia in Turkish population. Turk Psikiyatri Derg. 2002;13:273-81. advanced age: a meta-analysis of intervention studies. Psychol Aging. 2005;20:272.

14. Beaton DE, Bombardier C, Guillemin F, et al. Guidelines for the process of crosscultural adaptation of self-report measures. Spine. 2000;25:3186-91.

15. Koo TK, Li MY. A guideline of selecting and reporting intraclass correlation coefficients for reliability research. $J$ Chiropr Med. 2016;15:155-63.

16. Kilic S. Cronbach's alpha reliability coefficient. Psychiatry and Behavioral Sciences, 2016;6:47-8

17. Hayran M. Sağlık araştırmaları için temel istatistik: Omega Araştırma; 2011.

18. Helmerhorst HHJ, Brage S, Warren J, et al. A systematic review of reliability and objective criterion-related validity of physical activity questionnaires. Int $J$ Behav Nutr Phys Act. 2012;9:103.

19. Herbolsheimer F, Riepe MW, Peter R. Cognitive function and the agreement between self-reported and accelerometeraccessed physical activity. $B M C$ Geriatr.2018;18:56.

20. Heij W, Teerenstra S, Sweerts L, et al. Implementation of a Cost-Effective Physical Therapy Approach (Coach2Move) to Improve Physical Activity in CommunityDwelling Older Adults With Mobility Problems: Protocol for a ClusterRandomized, Stepped Wedge Trial. Phys Ther. 2020;100:653-61.

21. Siebeling L, Wiebers S, Beem L, et al. Validity and reproducibility of a physical activity questionnaire for older adults: questionnaire versus accelerometer for assessing physical activity in older adults. Clin Epidemiol. 2012;4:171

22. Puhan M, Siebeling L, Beem L, et al. Validity And Reproducibility Of The LASA Physical Activity Questionnaire (LAPAQ). In. A38 Understanding The Psychosocial And Behavioral Factors Affecting Outcomes In Lung Disease: ATS; 2011. p. A1453-A.

23. Koolhaas CM, van Rooij FJ, Cepeda M, et al. Physical activity derived from questionnaires and wrist-worn accelerometers: comparability and the role of demographic, lifestyle, and health factors among a population-based sample of older adults. Clin epidemiol. 2018;10:1. 